\title{
The science centre movement in Índia: a conspectus
}

\section{O movimento dos centros de ciência na Índia: um resumo}

\author{
Ingit Kumar Mukhopadhyay \\ Director of National Council of Science Museums, India \\ H6/9 Labony Estate \\ Salt Lake \\ Kolkata -700064 \\ India \\ ncsmin@giasc.vsnl.net.in
}

MUKHOPADHYAY, I. K.: The science centre movement in Índia: a conspectus.

História, Ciências, Saúde - Manguinhos, v. 12 (supplement), p. 281-307, 2005.

The present article is about the development of the science museum net in India started in 1956, when the government of that country created the Industry and Technology Museum in Calcutta. In the 1960 's and 1970's, due to the need of simple programs for rural communities and small villages, the idea of Mobile Science Exhibits (MSE) started. In order to take universal scientific concepts to those who could not visit museums, the Museobus was projected. At that time, the educational focus in museums changed from exhibiting artifacts to encouraging learning through "doing". The

Exploratorium in San Francisco influenced the approach of museums in India. While the first Science Centre was built in Mumbai, the Planning Commission of the Indian government created a task force to study the development of Sciences Museums. In 1978, the National Council of Science Museums (NCSM) was created as an independent institution, which later became part of the Ministry of Education and Social Welfare. Twenty-five years after the creation of the Council, the movement for informal science teaching had acquired a solid background. In 1978, their priority was to expand the net of Science Centres and Museums. Now, the priority is to achieve better quality and more efficient communication. Nowadays, Indian Science Centres evaluate the impact their activities have on individual, social and economic reality. With new technologies and approaches, they try to emphasize their relevance in a society that is characterized by having a great number of languages and poor education in science.

KEYWORDS: India, science centres, science museums, National Council of Science Museums, education in science.

MUKHOPADHYAY, I. K.: O movimento dos centros de ciência na Índia: um resumo. História, Ciências, Saúde - Manguinhos, v. 12 (suplemento), p. 281-307, 2005.

Este artigo trata da evolução da rede de museus de ciência na Índia desde 1956, quando o governo deste país estabeleceu um Museu Industrial e Tecnológico em Calcutá. Nos anos 1960-70, colocou-se a necessidade de programas simples que atraíssem as comunidades de vilas rurais e pequenas cidades. Surgiu, então, o conceito de 'Exposição de Ciência Móvel' (MSE): levar até aqueles que não podiam ir aos Museus as mensagens universais da ciência por meio de um ônibus projetado com este fim, o 'Museobus. O conceito de educação nos Museus mudou, então, substituindo-se a ênfase em artefatos pelo conceito de se aprender "fazendo".

O Exploratorium criado em São Francisco influenciou os Museus de Ciência indianos. Enquanto era construído o primeiro Centro de Ciências em Mumbai, a Comissão de Planejamento do governo indiano criou uma força tarefa para estudar o crescimento dos Museus da Ciência. Em 1978, incorporou uma sociedade autônoma - 'Conselho Nacional de Museus da Ciência' (NCSM) - depois anexado ao Ministério da Educação e do Bem-estar Social. Quando este Conselho completou 25 anos, tinha adquirido uma posição sólida o movimento do ensino de ciência informal. Em 1978, a prioridade era a expansão da rede de Museus e Centro de Ciência. A prioridade agora é a qualidade e a comunicação mais eficiente. Os Centros de Ciência indianos atualmente estudam o impacto de suas atividades nos níveis individuais, sociais e econômicos. Com a adoção de novas tecnologias e abordagens, tentam conservar sua relevância numa sociedade caracterizada pela diversidade de idioma e costumes e pela falta de instrução científica.

PALAVRAS CHAVES: Índia; centro de ciências, museus de ciências; Conselho Nacional de Museus da Ciência; educação em ciência. 


\section{CHAPTER I}

\section{EVOLUTION OF THE SCIENCE MUSEUM NETWORK IN INDIA}

N on-formal science education through Science Museums took its root in India fifty 1 years back when two Science Museums opened their doors to the public at Pilani, Rajasthan and New Delhi. The Central Museum inside the BITS (Birla Institute of Technology \& Science) campus at Pilani and the museum inside Nationa 1 Physical Laboratory (NPL), New Delhi premises offered new opportunities to people for learning science at their own leisure time and more significantly, in a new way completely different from the formal mode.

The idea of extending science and technology education through the medium of Science Museums got a filip when the Government of India decided in 1956 to set up an organised Industrial \& Technological Museum at Kolkata following the European model. At that time, the Deutsches Museum at Munich, Germany and the Science Museum, London were recognised as leading institutions in the field and naturally their activities and displays strongly influenced the first Science \& Technology Museum in India.

The Birla Industrial \& Technological Museum (BITM) opened its doors on 2nd May 1959 with seven galleries on Metallurgy of Iron \& Steel and Copper; Petroleum; Electricity; Nuclear Physics; Electronics; Television; Optics \& Miscellaneous. Soon it became the talk of the town and students of this large metropolis fo und in it a treasure house of working exhibits and absorbing demonstrations of scientific principles. Encouraged by the success of the BITM and realising the potential of a Science \& Technology Museum in popularising science among the people at large, the Council of Scientific and Industrial Research (CSIR) under the control of which BITM was functioning, decided to set up a similar institution at Bangalore which, during the 60's was fast growing to be a significant hub for scientific activities in the region. The Visvesvaraya Industrial \& Technological Museum (VITM) opened its doors to the public in 1965. Soon the VITM grew into an extremely popular institution for the students in and around Bangalore. Within a few months, the museum became one of the major tourist attractions of Bangalore. With this, Science Museums laid strong and dependable foundation on the soil of Indian science education scenario.

In the 60's and early 70's science museums took wings out of the large metropolitan cities and established themselves in rural areas some of which were predominantly tribal and economically backward. The rural foray of Science Museums called for simple and activityintensive programmes that invited participation of various communities in villages and small towns. New target groups, distinctly different from students, were found out and offered awareness programmes on various issues of Science \& Technology. These programmes also proved to be immensely popular. Soon, both BITM \& VITM started receiving strong demands from science teachers of schools in villages and district towns for conducting programmes for both students and local communities. However, for obvious reasons, large parts of the country, particularly rural areas could not be covered with science programmes at a time. The thrill of science learning in the museum environment remained largely confined to large cities and some other towns.

The concept of 'Mobile Science Exhibition' (MSE) took shape in this background. For those who could not come to Science Museums, the universal messages of science 
were to be taken to them. The MSE was first introduced by BITM in the middle of 60's a specially designed bus on a standard bus/truck chassis having exhibits on a scientific theme mounted on the bus along with other hardware, film projector, power generator and spares. The bus, usually referred as 'Museobus', used to carry an explainer to conduct programmes, a mechanic for regular maintenance and the driver who used to drive and look after the bus. For almost forty years now, the Museobus is taking science education to far-flung areas and offering current information on Science \& Technology to people who do not have any interface with the so-called temples of knowledge in big cities.

After Kolkata and Bangalore, it was time for Mumbai to have its own Science Museum. In the mean time, particularly in the sixties, the concept of education in Museums was changing rapidly from the artefact-based mode to an activity-based process. The main idea was to incorporate a shift from a 'seeing and reading' mode to a 'doing' mode in learning science. The Exploratorium in San Francisco and some other institutions introduced the 'Science Centre' concept into the non-formal science education scenario. The exhibits put up in these institutions were creative, interactive, option-laden and designed to be selfexplanatory. Such arrays of exhibits were quite different from the traditional themebased exhibits in existing Science Museums highlighting messages through related artefacts. Each of the new interactive exhibits in science centres was designed to convey some message or principle of science through a two-way enjoyable communication between the exhibit and the user. Experiments by way of trying out various options given in the exhibit brought in new components of fun and discovery in the learning process. The Exploratorium, as a pathfinder, influenced many Science Museums in the world including the Indian Science Museums. In this context, it was decided that the new facility at Mumbai would be a Science Centre - the evolved avatar of Science Museums.

Planning for the Centre at Mumbai started in early seventies. After a rigorous groundwork, a plot of land in the heart of the city at Worli, was selected for setting up the main Science Centre in Western India. The plot was still available at that time in a city like Mumbai where construction industry was booming, because it was a part of the city's garbage dumping area - filthy, smelly and out-of-bounds for the citizen on the street. However, in course of time, as the Nehru Science Centre took shape, there was a definite environmental upgradation of the whole locality. Thus, the Nehru Science Centre became an active agent for improvement of the entire area adjacent to the centre. Today, by visiting the green, shadowy premises of the centre, no one would even imagine that the same was a stinking garbage dump thirty years ago.

While the first Science Centre was being built in Mumbai, the Planning Commission of the Government of India constituted a task force to asses the activities of the Science Museums functioning under CSIR and recommended the course of action to be taken for the growth, sustenance and adequate use of these institutions. The task force saw immense potential of the Science Museums for creation of science awareness and a scientific temper among the people at large and made several recommendations. The most important of them were

i) science museums are to be developed in three levels - national, regional \& district level supported by mobile science exhibition units.

ii) the Science Museums to be set up in different parts of the country need not be of the same type nor should they follow a uniform model in terms of their size, 
nature and scope. However, the museums may have a common basic core element supplemented by sections relevant to the local conditions.

iii) for the planning of the network of Science Museums, there should be a separate executive agency with required specialisation and expertise.

The Governing Body and the Society of CSIR accepted the recommendations of the task force and later, the Government of India decided to incorporate an autonomous society titled 'National Council of Science Museums' on 4th April 1978. The existing Science Museums at Kolkata, Bangalore and Mumbai were subsequently delinked from CSIR and their control was taken over by the NCSM. During incorporation, the NCSM also received the mandate of developing new Science Museums and Science Centres in the country and running them for the benefit of the society. Following the delinking from CSIR, the NCSM was attached to the Ministry of Education and Social Welfare as the user Ministry in the Government of India.

From 1978 to 2003 when the Council completed its 25 Years of existence, the Science Centre activities in India witnessed an explosive growth that put non- formal science teaching movement in the country on a strong and wide footing. Due to its widespread activities both in the urban and rural areas set up through a well connected network, the National Council of Science Museums received attention and recognition from all parts of the world and in some cases became the role model of science centres in many developing countries. The NCSM network functions on a 3-tier orientation with 4 national level centres in Kolkata, Bangalore, Mumbai and New Delhi. Each of such national level centres - usually having a floor area between 12,000 to 20,000 sq.mtrs. with a strong exhibit development centre, has under its control a number of Regional Science Centres (RSC) and Sub-Regional Science Centres (SRSC, also called District Science Centres). The RSCs are usually located in State capitals catering to more than one million people while the SRSCs are often located in small district towns, tribal areas or economically backward areas.

From three units in 1978, the NCSM network grew to 14 units in 1993 and to 28 in 2003. At present, in addition to the major national level centres, the Central Research \& Training Laboratory and the Science City, there are 9 Regional Science Centres and 13 SRSCs functioning from different parts of the country. The NCSM leads the science museum and science centre movement in India and therefore most of the information given in the following pages will relate to the performance of NCSM. However, the policies followed by NCSM are more or less the same as done by other science museums and science centres outside the control of NCSM. Therefore, the NCSM truly represents the science museums and science centres of India at present. 


\section{Infrastructure development over the last five decades}

\begin{tabular}{|c|c|c|}
\hline Decades & \multicolumn{2}{|c|}{ No. of Science Museums/Centres } \\
\hline & Under NCSM & Outside NCSM \\
\hline $1951-1960$ & 01 & 01 \\
\hline $1961-1970$ & 01 & 01 \\
\hline $1971-1980$ & 01 & \\
\hline $1981-1990$ & 07 & 03 \\
\hline $1991-2000$ & 16 & 04 \\
\hline $2001-2003$ & 02 & 02 \\
\hline TOTAL & $\mathbf{2 8}$ & $\mathbf{1 1}$ \\
\hline
\end{tabular}

- Sikkim Science Centre, Gangtok

- Manipur Science Centre, Impha 1

- Nagaland Science Centre, Dimapur

- Arunachal Pradesh Science Centre, Itanagar

- Meghalaya Science Centre, Shillong

- Maharaja Ranjit Singh Panorama, Amritsar (Historical)

- Regional Science City, Lucknow

- Kalpana Chawla Memorial Planetarium, Kurukshetra

- National Agricultural Science Museum, New Delhi

- Regional Science Centre, Ranchi

- Regional Science Centre, Coimbatore, Tamilnadu

- Pushpa Gujral Science City, Jalandhar

- Science City, Gujarat
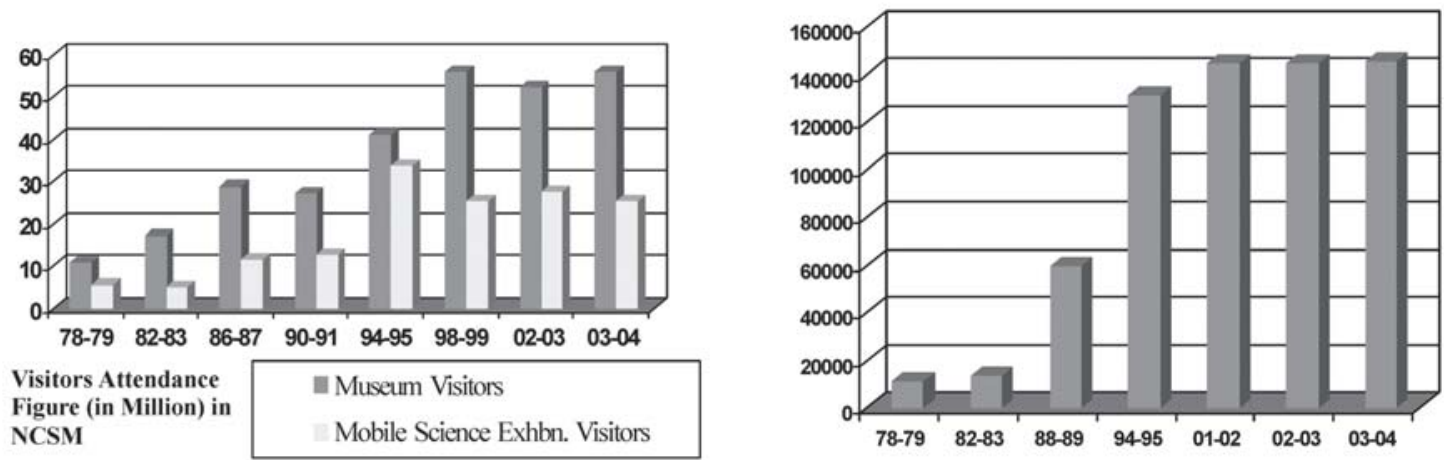

Growth of Floor Area (Sq.Mt.) in NCSM 


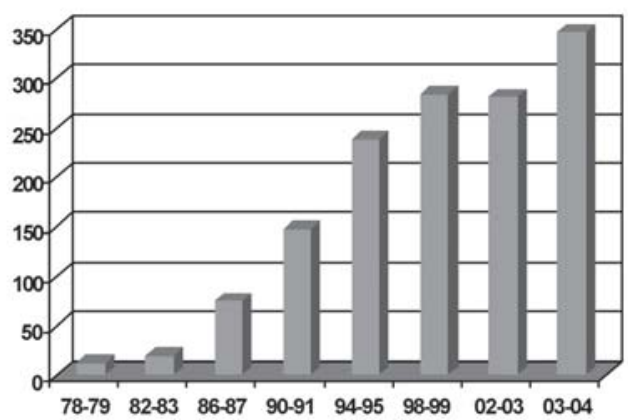

Increase in Gross Expenditure of NCSM (Rs. in Million)

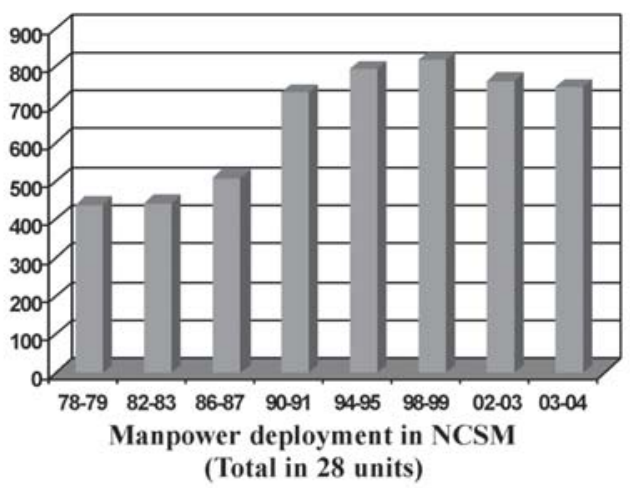

(Total in 28 units)

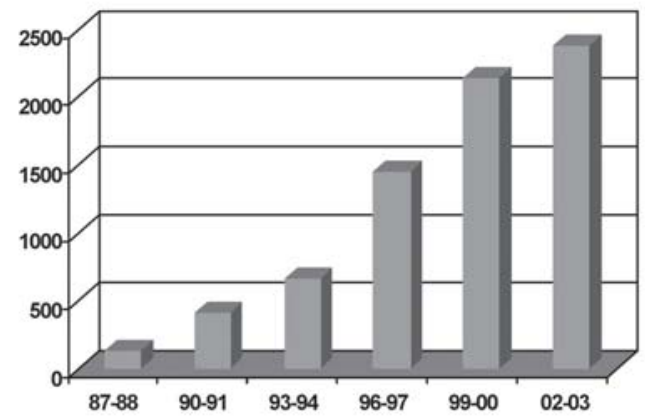

Increase in Capital Asset of NCSM (Rs. in Million)

\section{SCIENCE MUSEUMS AND SCIENCE CENTRES UNDER NCSM}

www.ncsmindia.org www.ncsm.org.in
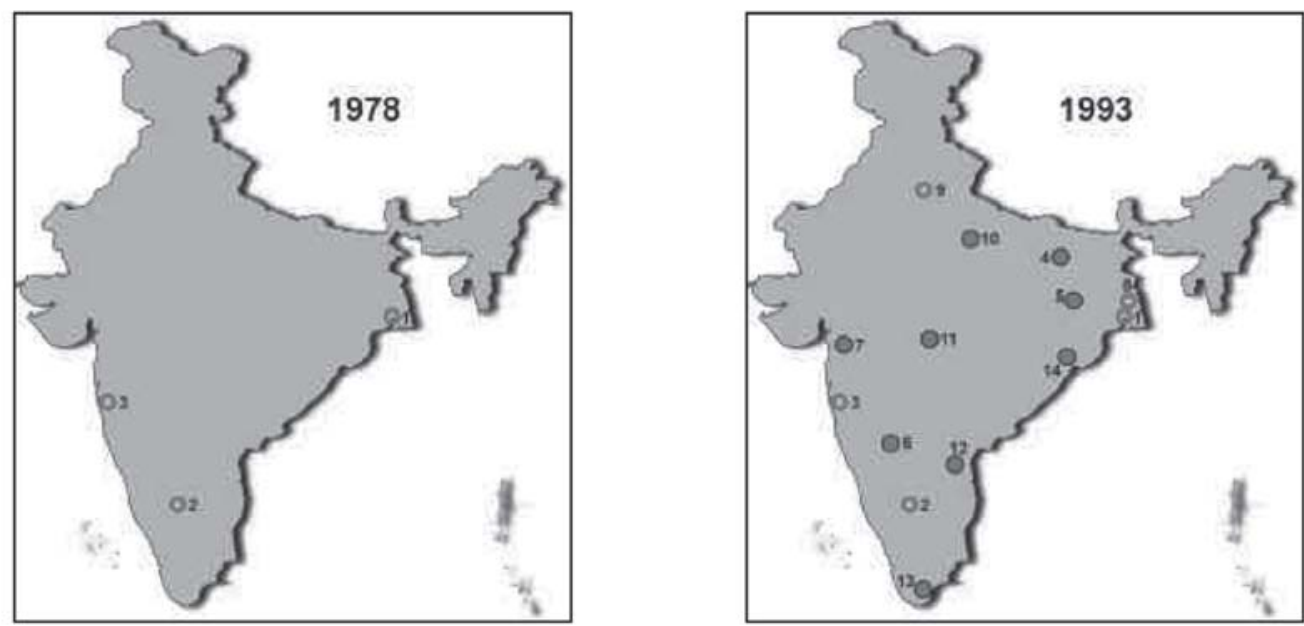


\section{The Rural Foray}

One of the important objectives of the NCSM being proliferation of scientific awareness among the rural masses, educational activities directed to rural and semi-urban masses were initiated in the sixties in a limited scale. With the strengthening of the network infrastructure, such activities gained momentum in the eighties. For those who cannot come to the science museums or centres in cities or district towns, NCSM endeavours to carry the message of science to far-flung corners of the country by way of cond ucting Mobile Science Exhibitions (MSE). Such exhibitions, mounted on specially designed 'Museobuses' travel to all corners of the country carrying with it thematic exhibitions on scientific topics relevant to the life of those who live in villages. The mobile exhibition is supplemented by science films, shows, science demonstration lectures, computer-based programmes and many other interesting hands-on activities for members of specific rural communities. These are continuously monitored and upgraded by the regional network of science centres and quite often, the demand for a MSE in villages exceeds the supply capacity. Currently a fleet of 22 Museobuses operate in different parts of the country. Special design for the Museobus is now being worked out for easy movement in hilly areas and also in areas where roads are not well developed. Satellite connectivity and an extended scope for the mobile exhibition are also being planned for incorporation in the new design.

\section{Priorities and Policies}

Infrastructure development had been NCSM's top priority in 1978, when the Council started functioning. During the last 25 years, a wide network covering almost all states and union territories has been established. This growth in physical establishments buildings, facilities, equipments, trained manpower etc. has put the Council on a solid base by the turn of the century. However, from the beginning of the 9th plan period in 1997, main priorities were fixed on consolidation, quality and efficiency through optimization. The Council is currently operating from 28 locations and it was decided not to increase the physical infrastructure of the Council further in a big way as witnessed during the '80s and '90s. On the other hand, the growth is being sustained by making the existing units of NCSM more modern, effective and technology-conscious and by establishing Science Centres in hitherto unrepresented areas on a turnkey basis by NCSM expertise and handing them over to the state or local authorities after inauguration. To maintain quality of activities conforming to the NCSM norms, continuous monitoring is done and full technical support is given by the Council to such centres handed over to local authorities. One of the major initiatives taken in the 10th plan (starting 2002) period is establishment of Science Centres in all the States in the North-East and also in the Andaman \& Nicobar Islands. These modern Science Centres in geographically remote areas have now become hubs of scientific activities for the local communities in general and the students in particular. This way, the science centre movement is becoming regenerative and the target is to give the movement decentralised local bases. Thus, the spread \& penetration of non-formal science education is expected to receive a wider and stronger thrust in years to come. 
The interest grown at the grassroot level in Science and Technology gave rise to the foundation of Science Clubs in almost all States of India.

Number of Science Clubs in India (Statewise)

Source: Department of Science \& Technology, Government of India

$\begin{array}{llllll}\text { Andhra Pradesh } & -05 & & \text { Meghalaya } & -03 & \\ \text { Arunachal Pradesh } & -03 & & \text { Mizoram } & -01 & \\ \text { Assam } & -25 & & \text { Madhya Pradesh } & -52 & \\ \text { Bihar } & -21 & & \text { Orissa } & -16 & \\ \text { Delhi } & -03 & & \text { Pondicherry } & -01 & \\ \text { Goa } & -14 & & \text { Punjab } & -10 & \\ \text { Gujarat } & & -04 & \text { Rajasthan } & & -06 \\ \text { Haryana } & -05 & & \text { Tamilnadu } & -36 & \\ \text { Karnataka } & -06 & & \text { Tripura } & & -72 \\ \text { Kerala } & & -01 & \text { Uttar Pradesh } & & -108 \\ \text { Maharashtra } & -06 & & \text { West Bengal } & -60 & \\ \text { Manipur } & -07 & & & \end{array}$

Total: 465 registered clubs till November 2003. There are many other unregistered Science Clubs operating in different states.

\section{CHAPTER 2}

\section{EVOLUTION OF EXHIBITS}

By the end of the '50s, the two major Science Museums at Pilani and Kolkata were displaying models and exhibits through thematic presentations. The displays had a distinct European flavour and the exhibition floors had exhibits, mostly fabricated, to narrate a story of the development of a branch of science or technology. The thematic galleries had beautifully made dioramas, original artifacts and some scaled-down replicas of original artifacts (steam engines etc.). In both the museums mentioned above, Science \& Technology related themes were presented with exquisitely made dioramas and working models, but in general, the galleries lacked the excitement of learning through visitor's participation. Collection of original artifacts was a very important activity because those were considered extremely valuable for authentic presentation of a theme. Unfortunately, land mark artifacts were not easy to find and so, the use of replicas was resorted to in many cases. The Birla Museum, Pilani, still displays very nicely made dioramas, cut-section engines, turbines and the like and they are still found to be quite attractive in the traditional scheme of thematic displays in the areas of Energy, Metallurgy or Communication. Other than a few simple audio-visuals, most of the supplementary information was given in the galleries through charts, posters or other visuals.

During the middle of the '60s, a group of exhibits under the title "Popular Science" was created and displayed in the galleries following the "Popular Mechanics" exhibits developed in major European museums at that time. There were exchanges of senior personnel between the Birla Industrial \& Technological Museum and some of the major museums in Europe like the Science Museum, London and the Deutsches Museum, Munich. The Indian exhibit designers used to go to Europe, study the exhibits and come back to reproduce many of them. A very important development in the Science 
Museums in Kolkata and Pilani took place at this time. In both the places, captive exhibit development laboratories were set up. Fabrication of exhibits for the galleries was done in these laboratories after necessary experiments were conducted and prototype designs made. Outsourcing was not much in vogue although skilled infrastructure was available in Kolkata in abundance. The exhibits used to be built on the shop floor on the basis of reference materials, often photographs and also experimentation.

In the '70s, the existing Science Museums particularly at Kolkata and Bangalore were influenced by the participatory approach in exhibit design. With about 15 years experience in the bag, the exhibit designers in India keenly studied the interactives developed in the US science centres particularly the Exploratorium and introduced exhibits of similar class in the Indian science centres. At this time, the recommendations of the Task Force of the Planning Commission under the Government of India were to be implemented indicating a huge potential for setting up new science museums and developing new exhibits. This is the time when the "Science Centre" concept was adopted in India and it was decided that the envisaged growth would create more activity oriented exposition than artifact oriented thematic presentation. The new institutions that followed the science museums in Kolkata (BITM) and Bangalore (VITM) were designed on the basis of "Science Centre" approach.

The Nehru Science Centre in Mumbai was set up with a large number of interactives but also 'with a few thematic galleries having traditional displays. The Centre at Mumbai was started with a pioneering approach towards science education through fun and enjoyment by way of creating an outdoor "Science Park". For the first time, science learning was to take place outside the four walls. The outdoor exhibits had a different set of design criteria and it was thought that learning of science while playing with the outdoor science park exhibits could be a bonus to the fun and enjoyment of playing. For example, a set of swings were placed in the park with three different lengths. While swinging, one could understand that no matter how much force one puts to swing, the longest one would always be the slowest. The curiosity of the visitor was then answered and validated by exposing him or her to a series of games related to oscillations. The entire process of learning took place through fun and play in a gay outdoor ambience. In India, where outdoor activities can be had during most part of the year, the science parks became instant hits with science centre visitors. In course of time, the outdoor element was incorporated in all the science centres developed by the NCSM.

In the middle of '80s, new science centres outside the NCSM chain were developed in Chennai (Madras), Tiruvananthapuram, Hyderabad, and Ahmedabad using the interactive science learning approach extensively. The Birla Museum at Pilani developed a new hall on "Popular Science" with interactives. During the early '90s, computeraided supplementary exhibit s appeared in the Indian science centre scenario - particularly in science centres of the NCSM. A remarkable event that took place at that time was the founding of the Central Research \& Training Laboratory (CRTL) at Kolkata under the NCSM for the purpose of catering to the R\&D and training needs of employees in the science centre profession in India. The CRTL concentrated on development of computeraided exhibits, new display and animation systems and formulated specific training schemes for science centre workers at different levels. At this stage, the growth of science centres in India was very fast, calling for some standardization in the dimensions of a few functional parameters of new science centres. Thus, many of the science centres in 
the regional and sub-regional level developed in the '90s in India, are found to have equal built up areas, almost identical auditorium facilities and an identical manpower deployment. The initial capital investment for such new science centres was put under a ceiling. This ceiling, however was extended periodically to match with the escalating prices and also with introduction of more sophisticated equipment and accessories. In the early'90s, NCSM started developing exhibits for experience-based learning, creating one after another specific 3-D frames of reference for explaining various principles of science \& technology. Added to this, was the use of large format film projection units, various types of simulators and exhibits on virtual reality. Two more science centres in Agartala in the North- Eastern State of Tripura and Jaipur in the state of Rajasthan started functioning outside the NCSM chain. The last decade of the 20th century saw a rise in the demand for exhibits made by NCSM not only in India but also outside. Science Centres developed in Australia, Israel, Turkey, Mauritius and Bangladesh procured exhibits from the NCSM, India for use in their own science centres. At the beginning of the 21st century, a conscious decision was taken in the NCSM for fast adoption of new technologies for science communication particularly on the digital electronics platform. By this time, groups of exhibit designers with some years of experience, started developing quality multimedia programmes and a series of new software tools for linking hardware elements with custom-built computer programmes to be used in exhibits. The trend is growing and at present, teams are being trained for production of high quality multimedia programmes and also for conducting various programmes over the digital medium. Very soon, the major science centres under the NCSM are going to be linked with ISDN lines and a few mobile science exhibition units will have satellite connectivity so that science programmes can be shown in deep rural areas of India through special arrangements with the networked science centres.

In addition to the permanent galleries, the NCSM, the Tamilnadu Science \& Technology Centre in Chennai and the B.M. Birla Science Centre at Jaipur develops temporary exhibitions on various themes on Science \& Technology having current relevance. The established network of the NCSM and the standardization of the physical infrastructure, particularly the exhibition halls in various centres immensely helped in handling such exhibitions which could be circulated over the Indian network very conveniently in a short space of time without adding to or modifying the existing facilities available in this huge network of science centres. Exchange of information regarding exhibits and application of new technology takes place continuously through an internal administrative system in the NCSM. Of late, exhibit designers from science centres outside the NCSM have started joining in such exchanges.

\section{CHAPTER 3}

\section{PROGRAMMES: Education in the Forefront}

As Science Centres have a major role in supplementing the formal science education system by way of offering experiment-based learning ambience, all the NCSM centres actively create a learning atmosphere where students (and adults too) of various levels find a scope of 'doing' science. The exhibits and other participatory activities in all the units of NCSM offer to the visitors a number of experimental options through which 
one can discover the messages of science and technology oneself. Currently, organised students groups make up about $30 \%$ of the total visitors to NCSM units in the country.

A large number of programmes are conducted in each Science Centre throughout the year. Many of them are designed and directed for students while many others are conducted for Birla Industrial \& Technological Museum where school students of the region could take part in the fair to show scientific models made by themselves. The creative minds of the school students could thus be given a platform to flourish. The Students Science Fair soon became an immensely popular activity among the school teachers also in the region and later it was introduced in all the science centres of the NCSM and also out of it. Almost at the same time, the activity of Science Demonstration Lectures was introduced in BITM which was later taken to other science centres. In this activity, lectures on different subjects included in the school science curricula were conducted with live demonstration. For this purpose, the lectures were conducted either in the science museum in front of organized school group visitors or in school and college auditorium where the lecturer from the Museum could deliver the lecture in front of large classes. The demonstrations were such that they could be easily reproduced in the school laboratories and therefore, such demonstration lectures soon became a matter of interest for science teachers. A part of the Teachers' Training Programme introduced later, was based on such reproduction of gadgets and equipment for conducting Science Demonstration Lectures. It was strongly felt that the BITM and other science museums operating in India at that time, could not reach a very large population particularly in the rural areas of India. The reasons were that all the science museums were located in major cities and that due to various reasons, the school children of the rural area could not come to the city even once in a year to take part in science museum activities. In the year 1965 it was decided that for those who cannot go to the science centres, such institutions could endeavour to take the message of science to their doorsteps. Thus, the Mobile Science Exhibition programme was given a shape by taking exhibits on easily comprehensive and relevant scientific themes on specially designed bus which could travel to deep rural areas extensively. The Mobile Science Exhibition, nicknamed Museobus, was accepted by the rural sectors in a big way and very soon, demand for such MSE from schools located far from cities and towns started pouring in. The Museobus, in addition to the thematic exhibits, carry films and film projector, science demonstration lecture kits and various other equipment for engaging not only school students but also groups of the local communities. Students participatory programmes like Science Fair and Students Science Seminar started growing in the '70s and '80s. Various State Governments and other institutions joined hands with the science museums to conduct such programmes in blocks, districts and State levels. On an average, about 2,00,000 students take part in such programmes throughout India. Another participatory activity "Science Drama Competition" has been introduced recently and within a short time, it has become very popular. School drama teams take part in this competition throughout the country and they enact drama on specific subjects on S\&T for which scripts are usually written by the science teachers. Other interesting programmes like Students Design Competition, Students Engineering Fair, Science Quiz Competition, Computer Awareness Programmes and many new programmes have been introduced in course of time in the science museums/centres in India. 
A new initiative has been taken to make the educational programmes of science museums to reach a wider audience by developing science communication over the electronic media. A large number of educational CD-ROMs, VCDs are produced by the science center for use in schools. Every year NCSM produces two or three interesting traveling exhibitions on current scientific topics to expose newer areas to the people at large. Very recently, a "Virtual Laboratory" software has been developed by the NCSM to assist school students in learning laboratory work on subjects like Chemistry, Biology and Physics.

\section{CHAPTER 4}

\section{NEW INITIATIVES}

Since the beginning of the 21st Century, the NCSM has been functioning with 28 operating science centres and science museums located in different parts of India. The activities of the NCSM network is so popular in India that demands for setting up new science centres have been coming to the NCSM and the Department of Culture, Government of India from many State Governments. The growth of the infrastructure and its subsequent maintenance under the administration of the NCSM were very carefully examined to determine the nature of future growth of the science centre movement in the country. It was felt that administering a network larger than the present one may prove difficult for NCSM. But, at the same time, the messages of Science \& Technology need to be communicated to areas hitherto unrepresented by NCSM in this vast country with population more than 1 billion. It was decided that NCSM would set up science centres in different parts of the country particularly in the States and territories which so far do not have any science centre and later on, hand them over to the respective local authorities or societies formed by the local authorities for the purpose to operate and maintain such new science centres. On the basis of this decision, work for setting up new science centres started from 2001 in the North-Eastern parts of the country, island territories and also in the States which do not have science centre so far. During the financial year April 2003 to March 2004, two of the new centres have been opened to the public and three more are expected to be opened before March 2005. The remaining science centres for which work has already started at site will be opened in early 2006 as per the schedule. As a part of the package offered by the NCSM to State Governments for setting up new science centres, employees engaged by the State Governments to operate the new science centres will be fully trained by the NCSM and technical support from NCSM would be made available to the local authorities of State Governments even after such science centres are inaugurated and handed over to them. Thus the non- formal science education activities initiated by NCSM is now being regenerated at local or regional levels with full support from the Council and the Government of India.

The Tamilnadu Science \& Technology Centre has also embarked upon the job of creation of a network in the State of Tamilnadu in South India. New regional science centres at Trichi and Coimbatore have been developed under the funding of the Government of the State of Tamilnadu. The State will soon be networked under the overall control of the Tamilnadu Science \& Technology Centre, which is fast developing its capability in producing quality exhibits. 
The other very important and challenging issue in front of NCSM was consolidation and optimization of the huge network it controls. As a matter of fact, the infrastructure growth of the Council had been prolific in the ' 80 s and ' 90 s but the quality element and the human resource element were not adequately grown. Since 1997, these two areas have been taken up for development by way of continuous monitoring of the quality of the exhibits and exhibitions, survey of visitors reactions and conducting training programmes at all levels to impart new values and new capabilities to the existing human resource. Other functional major science centres outside the NCSM umbrella are located at Pilani, Chennai, Hyderabad, Jaipur, Trivandrum and Agartala. These centres and the NCSM units are in continuous dialogue on various issues related to Science Communication. The National Council of Science Museums network, as the largest Science Museum/Science Centre network in the world under a single administrative umbrella is leading science communication activities in the South Asian region and has its influence all over the world. NCSM currently operates under the Department of Culture, Ministry of Tourism \& Culture, Government of India.

\section{The Central Research \& Training Laboratory}

The substantial growth in the infrastructure of the Science Centre network in India generated an in-house demand for sophisticated exhibits and a training base for development of skill and capability in design and fabrication of efficient exhibits and equipments for meaningful science communication. For this purpose, the Central Research \& Training Laboratory (CRTL) of the Nationa 1 Council of Science Museums was established as a part of the NCSM headquarters facilities at Salt Lake, Kolkata. The CRTL spearheads new developmental work for exhibits with modern animation systems, new display techniques, various science communication activities on the digital electronics platform and also new types of 2D and 3D multimedia programmes. An inflatable Planetarium for interactive astronomy education is also manufactured by CRTL with license from a US Company. A few patents and copyrights ha ve already been generated from the activities of the laboratory. Capability building initiatives in the field of science communication has been given priority in the last few years in NCSM. The fruits have started to appear and the future growth of NCSM will be led through a quality-driven path for achieving more efficiency and worldclass service. Fortunately, recent team-building efforts have successfully generated a cuttingedge capability in NCSM and the Council's exhibit designers can now handle most of the modern technology driven science communication activities adequately.

The exhibit development expertise of NCSM units and particularly of CRTL is now recognised internationally. This is reflected in a continuous demand for catalytic support from other science centres and similar institutions in India and abroad. In the recent past, NCSM has given exhibits to science centres in Australia, U.K., Israel, Turkey and Bangladesh. The first Science Centre in Mauritius has been set up by NCSM on a turnkey basis. Several other proposals for setting up new science centres in other countries have been received by NCSM during the last one year. A separate research budget currently in the order of Indian Rupees 18.72 Million is provided and a separate research account is maintained. Some of the developments of the CRTL have received patents or copyrights. On the basis of this activity, the NCSM has been recognized by the Department of 
Scientific \& Industrial Research, Government of India as a Scientific \& Industrial Research Organisation. With this recognition, NCSM gets special tax benefits and exemption of duties for import of equipment from abroad.

It will be worth mentioning here that new approaches in planning new exhibit galleries are continuously tried in the Indian Science Museums. One interesting approach has been made while setting up a Regional Science Centre in Kurukshetra in the State of Haryana in North- Western India. Kurukshetra is well known to most of the Indians as the place described in the epic Mahabharata where the great war between Pandavas and Kauravas took place. This is also the place where the sermon of Bhagavad Gita was delivered as per the description given in the epic. For setting up a Science Centre at Kurukshetra, it was decided to have a focus on the 4500 year old heritage of Science \& Technology in the Indian sub-continent. A very large panoramic presentation on a cylindrical surface of $39 \mathrm{M}$ diameter and 12M height of the epical war has been displayed as the central exhibit. Various scientific signals described in the epic were taken from this story and explained in the light of the Indian heritage in Science \& Technology. The entire presentation was based on research conducted by well-known institutions in this field. The Panorama helped creating a very strong link with the story described in the Mahabharata and the history of development of Science \& Technology on the Indian soil. Although the Mahabharata war does not have any archaeological evidence, but almost every Indian knows the story of the epic and therefore, the presentation helped people very much in being curious bout the long standing Indian heritage in Science \& Technology. The Science Centre is one of the most popular Centres in the country.

\section{Impact Assessment}

As there is no reference point in respect of a research direction in the field of impact assessment of Indian Science Museum/Centre activities, it has been decided by NCSM to initiate survey, studies and research on this subject after initially identifying the data sources and also by taking a definite research plan. For this purpose, four fellowships are offered by NCSM and it is expected that work for such survey and research would progress well in 2004 - the Year of Scientific Awareness proclaimed by the Government of India. Work for the assessment has already started and it is expected that by the end of 2004, a relevant database will be available.

\section{Getting ready for the future}

The science centres operating in India try to take up the challenge of changing technologies by adapting them suitably through specific training programmes. It is well understood that in a vast country like India, a lot of science communication activities are going to take place over the internet or the digital electronics media as a whole in the coming years. Preparation for this has already been taken in various science centres by training groups of people for generation of new computer aided supplements, new multimedia programmes, software tools etc. Material to go in the internet or through distribution of CD-ROMs to schools and other institutions are being prepared in quantities. The four major centres in the NCSM at Kolkata, New Delhi, Mumbai and Bangalore will shortly be connected through ISDN lines and satellite connectivity will 
also be brought in. A Web Casting Studio is also being planned for generation and distribution of programmes on- line. New galleries and exhibitions being developed by the NCSM are all having internet connectivity in one or more places so that relevant sites can be accessed from inside permanent galleries.

A large majority of schools in the urban, semi- urban and rural set up in India will have access to computer-based teaching and in some cases internet connectivity too. By the end of the year 2004, in some States of the country, most of the schools would have computers in classes. However, many of such schools do not have good quality science laboratories. Even where the laboratories are operating, limited number of practical classes are held to optimize costs for running such laboratories. With this situation in view, the NCSM is currently developing a series of virtua 1 laboratories for conducting practical science classes in chemistry, biology and physics. The CD-ROMs on such virtual laboratories will be available to all the schools and also for private use. Major Indian languages will be used and the curriculum for practical science classes will be generally followed.

\section{Exposure of NCSM through Internet www.ncsmindia.org}
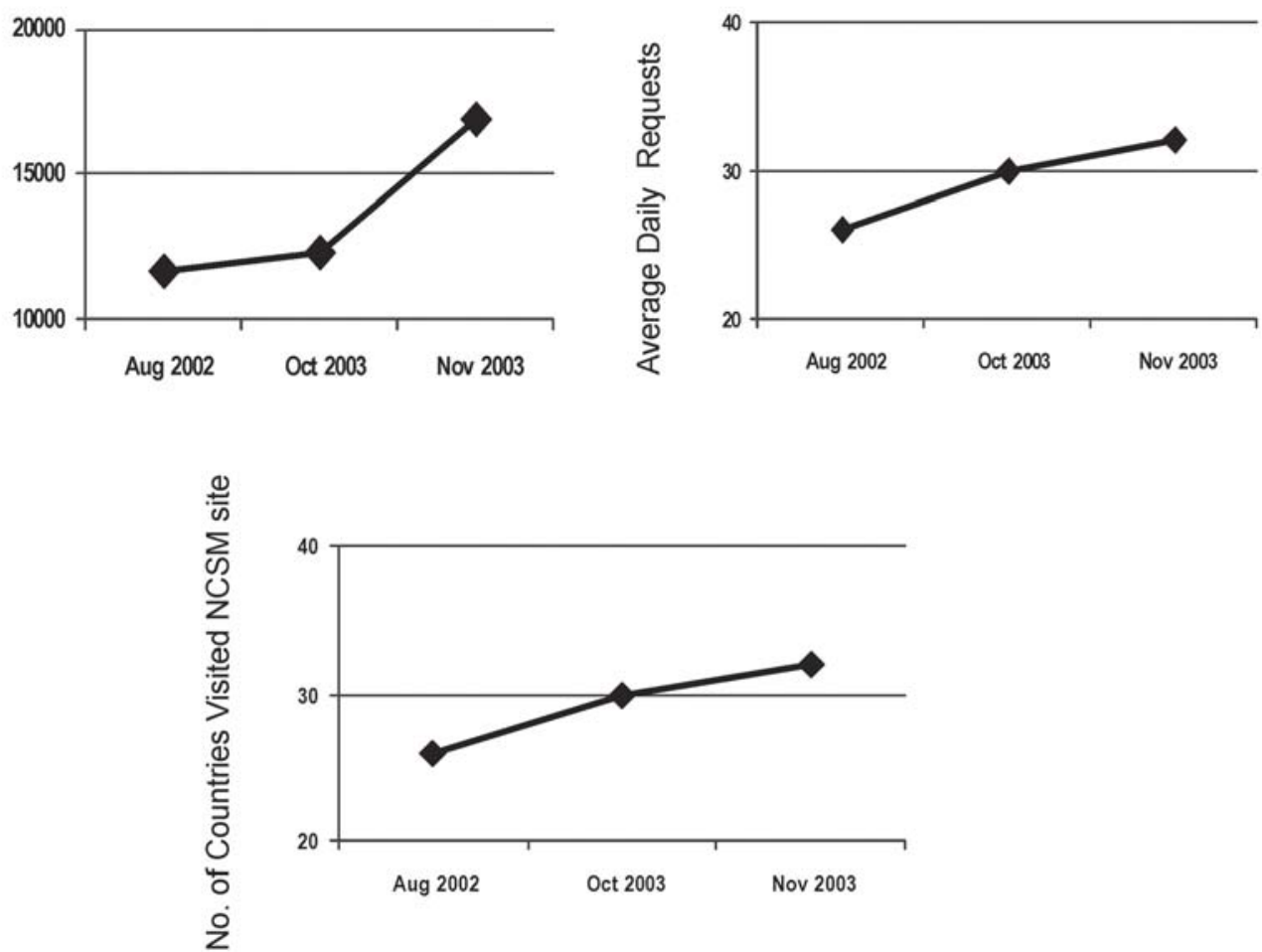


\section{CHAPTER 5}

\section{VISITOR DETAILS}

The Science Centres under NCSM network are visited by about 6 million people every year at present. In addition, the Mobile Science Exhibition units are visited by about 2.5 million visitors. Out of this, approximately $30 \%$ to $32 \%$ on an average comprise organized student groups. The figures for the other major science centres are as follows:

\begin{tabular}{|c|c|c|c|c|c|c|c|}
\hline \multirow[b]{2}{*}{ Institution } & \multicolumn{3}{|c|}{ Visitor to centre (A) } & \multicolumn{3}{|c|}{ Visitor to outreach programme (B) } & \multirow{2}{*}{$\begin{array}{l}\text { Website } \\
\text { visitors } \\
\text { (C) } \\
\end{array}$} \\
\hline & $\frac{\mathscr{2}}{3}$ & 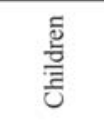 & 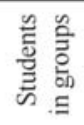 & $\frac{\mathscr{O}}{3}$ & $\frac{\sqrt{\frac{5}{2}}}{\frac{\pi}{0}}$ & 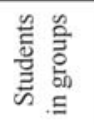 & \\
\hline $\begin{array}{l}\text { Birla Museum, } \\
\text { Pilani, Rajasthan }\end{array}$ & 90,000 & 30,000 & & & & & \\
\hline $\begin{array}{l}\text { Tamilnadu S\&T } \\
\text { Centre }+\end{array}$ & 50,744 & 77,535 & & \multicolumn{3}{|c|}{19,000} & \\
\hline $\begin{array}{l}\text { B.M. Birla } \\
\text { Planetarium, } \\
\text { Chennai }\end{array}$ & $1,06,393$ & $1,53,487$ & & & & & \\
\hline $\begin{array}{l}\text { Kerala State } \\
\text { S\&T Museum }\end{array}$ & 92,675 & 52,863 & 79,295 & 2500 & 195 & & \\
\hline $\begin{array}{l}\text { Sukanta } \\
\text { Academy, } \\
\text { Agartala, Tripura }\end{array}$ & 40,000 & 50,000 & 20,000 & &, 000 & & \\
\hline $\begin{array}{l}\text { B.M. Birla } \\
\text { Science Centre, } \\
\text { Hyderabad }\end{array}$ & \multicolumn{3}{|c|}{11 million } & & & & \\
\hline
\end{tabular}

\section{The Visitor Profile}

Visitors survey has been conducted in different units of NCSM throughout the last few years. Information compiled from such survey show the approximate visitors profile for different

\begin{tabular}{|c|c|c|c|c|c|c|}
\hline \multirow{3}{*}{$\begin{array}{l}\text { Genderwise } \\
\text { profile }\end{array}$} & & $\begin{array}{l}\text { BITM, } \\
\text { Kolkata }\end{array}$ & $\begin{array}{l}\text { Science } \\
\text { City }\end{array}$ & $\begin{array}{l}\text { RSC, } \\
\text { Nagpur }\end{array}$ & $\begin{array}{l}\text { RSC, } \\
\text { Bhopal }\end{array}$ & $\begin{array}{l}\text { NSC, } \\
\text { Delhi }\end{array}$ \\
\hline & Male & $65 \%$ & $78 \%$ & $70 \%$ & $72 \%$ & \\
\hline & Female & $35 \%$ & $22 \%$ & $30 \%$ & $28 \%$ & \\
\hline \multirow{5}{*}{$\begin{array}{l}\text { Occupationwise } \\
\text { profile }\end{array}$} & Students & $35 \%$ & & $44 \%$ & $47 \%$ & $59 \%$ \\
\hline & $\begin{array}{l}\text { Businessmen/ } \\
\text { Professionals/ } \\
\text { salaried people }\end{array}$ & $54 \%$ & & & $37 \%$ & $35 \%$ \\
\hline & Housewife & $7 \%$ & & & $7 \%$ & $6 \%$ \\
\hline & Tourists & & & $1 \%$ & & \\
\hline & Others & $4 \%$ & & $1 \%$ & $9 \%$ & \\
\hline $\begin{array}{l}\text { Repeat visitors } \\
\text { profile }\end{array}$ & & $48 \%$ & $33 \%$ & & & $41 \%$ \\
\hline
\end{tabular}




\section{CHAPTER 6}

\section{MANAGEMENT STRUCTURE}

It has been indicated earlier in this discourse that the Science Museums in Kolkata and Bangalore started functioning as a part of the Council of Scientific \& Industrial Research (CSIR) in India. The CSIR functions as a leading network of scientific and industrial research laboratories in India with its units spread all over the country. In the '50s, one of the major functions of the Science Museums was to portray the new developments in the various fields of science \& technology that was taking place in independent India. There was an identifiable focus on the Indian scenario in the planning and designing of each permanent gallery that came up during that time in the Birla Industrial \& Technological Museum, Kolkata, and the Visvesvaraya Industrial \& Technological Museum, Bangalore. The NCSM was set up in 1978, it was incorporated as a registered Society under the Registration of Societies Act XXVI of 1961 of the State of West Bengal with its registered office in Kolkata. The Society had representations of various social sections in its membership so that users from all strata of the society could be served adequately. The Minister- in-Charge of the Ministry or Department of the Government of India dealing with the NCSM Society is the President of the Society and eminent persons, not exceeding 19 in number, representing Science \& Technology, Education, Commerce \& Industry, Art \& Culture and Museology, are the members nominated by the Government of India. Other than this, members representing the Ministry or the Department, Financial Advisor to the Ministry, representative of the Department of Science \& Technology, Government of India, the Director General, CSIR, a representative of the Department of Technical Education, Government of India and the Director General, NCSM are the Ex-Officio members. The above constitution of the Society ensures that the NCSM maintains a direct relation with different social and economic sectors of national importance and also with the scientific, technological and educational wings of the government. The Director General of the Council functions as the Principal Executive Officer of the Society. The affairs of the Society are managed, administered, directed and controlled subject to the rules, bye-laws and orders of the Society by a Governing Body constituted for the purpose. The Governing Body of NCSM has in it renowned scientists, technologists, educationists; men from commerce \& industry, art \& culture and museology as members. The Director General is responsible for proper administration of the affairs and funds of the Society under the direction and guidance of the Governing Body. The Director General is vested with adequate executive and administrative powers for running the affairs of the Society. 


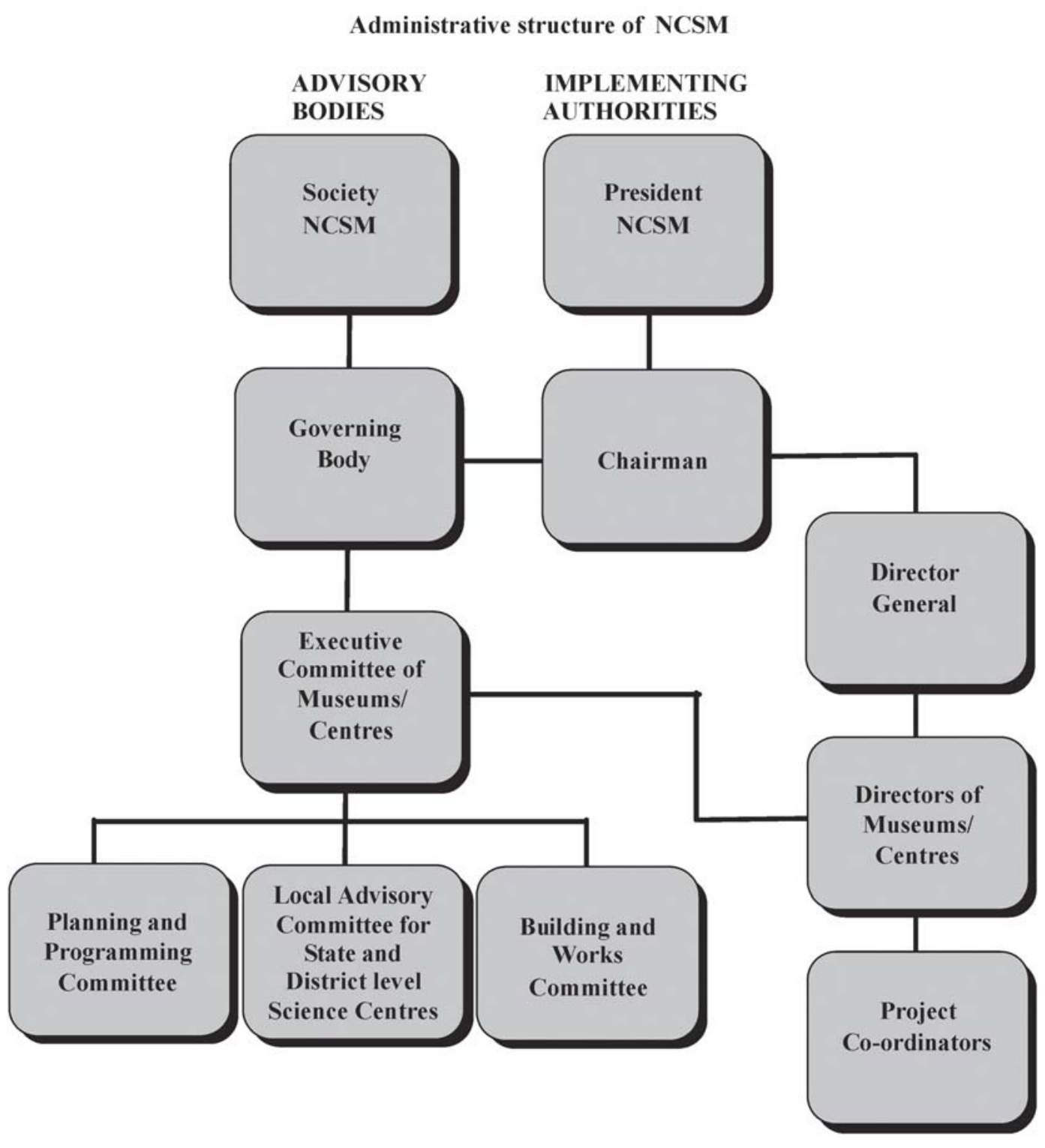

Among the other major science museums and science centres, the Tamilnadu Science \& Technolgy Centre which also runs a Planetarium, was established by the Government of the State of Tamilnadu. Another major Science Centre - Kerala State Science \& Technology Museum and Priyadarsini Planetarium in Thiruvananthapuram was established as a Government of the state of Kerala undertaking. Other smaller science centres like the Sukanta Academy at Agartala in the North-Eastern state of Tripura are established, funded and run by the respective State Governments. Among the science museums and science centres run with private funding, the Birla Museum at Pilani in the State of Rajasthan, the B.M. Birla Science Centre, Hyderabad, in the State of Andhra Pradesh and the B.M. Birla Science \& Technology Centre, Jaipur in the State of Rajasthan 
are important ones. The Birla Museum at Pilani is the oldest organized science museum in India which has completed 50 years of existence in the year 2003.

The National Council of Science Museums with 28 units spread all over the country has a fairly decentralized administrative structure with units in the North, South, East and West being coordinated by the four regional headquarters in the cities of Kolkata, New Delhi, Bangalore, and Mumbai. The 28 units of NCSM, on the other hand, has a three-tier structure. The large national level centres having a typical built up area of 15,000 to 20,000 sq.mtrs are located in Kolkata, New Delhi, Bangalore, and Mumbai. In addition, the Science City and the Central Research \& Training Laboratory are also located at Kolkata. The national level centres coordinate the function of Regional Science Centres located in the four zones in the country. The Regional Science Centres are medium level Science Centres having a built up area of 4000 sq.mtrs. and are set up with a capital investment of Rs.65.00 million. These centres are usually located in the State capitals or in large metropolitan cities having a population of more than one million. Each Regional Science Centre in its turn coordinates the activities of Sub-Regional Science Centres having a typical built up area of 1200 sq.mtrs. and located in smaller towns, economically backward areas or in areas where tribal population is significant. The rural foray of the Council is a designed activity since its inception. In the report of the Task Force made by the Planning Commission in the '70s as mentioned earlier and also in the objectives of the National Council of Science Museums framed during its incorportisation, care has been taken to see that the benefit of the science centre activities are not limited to the cities and major towns only but are shared in large proportions by the rural population of India.

The Central Research \& Training Laboratory (CRTL), set up by the Council in late '80s, caters primarily to the in-house demand of the Council for in-service training in various functions of science centre operation at different levels. The infrastructure is also used as a training facility by other countries of South and South-Eastern Asia. Significant research activities are taken in the laboratory in the areas of development of new exhibits, new animation and display techniques. Some of the research products are patented or put under copyright. Science Museums and Science Centres functioning in India outside the NCSM umbrella regularly uses the CRTL facilities for training of their staff.

The employees of the National Council of Science Museums are divided into three functional cadres - scientific, technical and administrative. The staff deployment pattern is shown in the illustration below: -

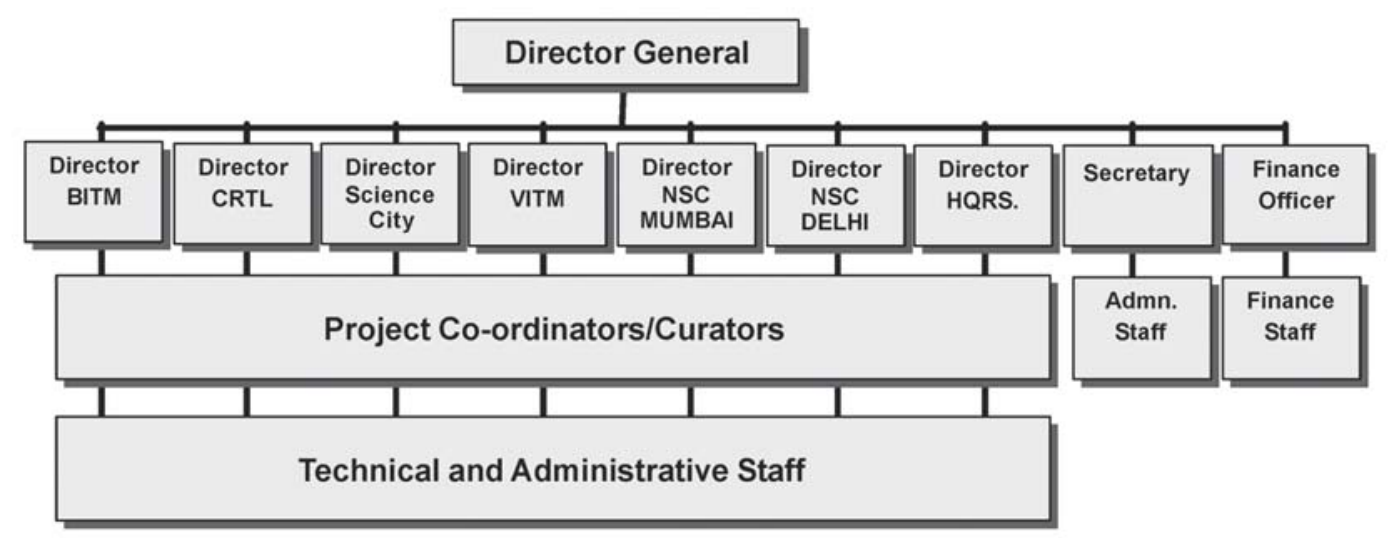


The Council is placed at par with the major scientific institutions of the country as far as the service conditions of the employees are concerned. The scientific and technical cadres are divided in four groups with new recruitment taking place at the entry level of the group. Promotion to higher grades are given on the basis of regular assessment of each employee in these cadres after a fixed period of residency in one grade. Such assessment and resulting promotion take place irrespective of any vacancy in the higher grade. The scientific cadre enjoys an assessment promotion benefit on the basis of a Flexible Complimentary System (FCS) at par applicable in major scientific institutions in India. Thus, entry of top-level students coming out of the universities to the Council is expected. The incumbents, however, are transferable to any of the units of the NCSM. The recruitment and the promotional avenues for administrative cadre employees which also includes persons working in the finance department take place in the same line as followed in the Government of India secretariats.

The Tamilnadu Science \& Technology Centre, Kerala State Science \& Technology Museum and the Sukanta Academy, Agartala enjoy service conditions of pay scales at par with the State Government employees of equivalent entry- level qualification and experience. Other science centres are run by privately funded society or trust and therefore, follow the service conditions offered by the society or the trust.

For the Curators working in the science centres under NCSM, the minimum entry level qualification is Master's Degree in Science or Bachelor's Degree in Engineering or equivalent. All degrees shall be first class and in disciplines relevant to the activities of Museum/Centre. All candidates shall have one year relevant experience after obtaining the degree. If there is any special requirement for any other equivalent professional degree for a particular post, approval from the Director General, NCSM shall be obtained before issuing advertisement so that uniformity in policy is maintained in the Council.

At present, out of the 48 Curators working in the Council, there are 8 PhDs., 20 Master's Degree holders and 20 Bachelor's Degree holders in Engineering.

\section{CHAPTER 7}

\section{FUNDING}

Out of the 40 science museums and science centres currently operating in India, 34 receive major funding from the Central or State Governments. The others are funded either by trusts or by private bodies. Over the years, as the demand for creation of new science centres grew, the Government of India supported the growth by increasing the fund size or by sharing the capital fund requirement with the state governments. Normally, for setting up a new science centre in the regional or sub-regional level by NCSM, the total capital fund required is shared equally by the central government and the state government. The plots of land on which such centres are set up are given free of cost by the state governments. For special category territories like in the States in North-Eastern India and the Islands, fund is shared in the ratio of 90:10 by the central government and the local government respectively. At the current ratio, the Sub-Regional Science Centres require an initial capital fund of Rs.20.00 million and for a Regional Science Centre this figure is Rs.65.00 million. For larger projects like Science Cities, which 
require a setting up fund of approximately Rs.700.00 million, the capital cost is shared in the ratio of 13:13:74 by the central government, the state government and private funding respectively. The norms for science cities have been established recently and putting this funding pattern in effect, is yet to materialize fully.

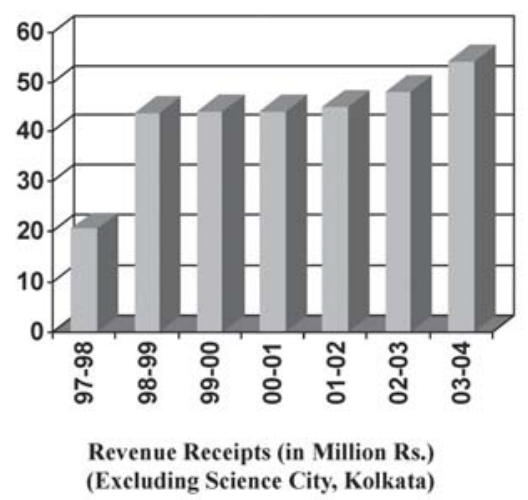

India is currently emerging as an industrial power. The service sector and the manufacturing sector are showing vast improvements. This has resulted in availability of fund with corporate bodies for sponsoring museums and museum related activities. In many cases the ind ustrial houses want to set up science centres with focus on the specific technology they use. In some other cases, sponsorship for setting up new galleries in existing science centres on specific areas of Science \& Technology are available from corporate bodies. The NCSM is wellknown for its expertise in setting up science centre and science museum galleries and therefore, many such corporate bodies in the agriculture sector, oil sector, electronics manufacturing sector and pharmaceuticals are using the NCSM expertise for setting up either their own science centre or new galleries in existing centres of NCSM.

The funding pattern for the NCSM, the Tamilnadu Science \& Technology Centre, Kerala State Science \& Technology Centre, The Birla Musum, Pilani and the Sukanta Academy, Agartala are given below. These are representative patterns, that may change according to the priorities and policies of the governments.

\begin{tabular}{|c|c|c|c|c|c|}
\hline \multirow{2}{*}{ Institution } & \multicolumn{4}{|c|}{ Source of Income for financial year 2003-04 (in million INR) } \\
\cline { 2 - 6 } & $\begin{array}{c}\text { Public } \\
\text { (Entry Fee) }\end{array}$ & $\begin{array}{c}\text { Private } \\
\text { (Donations/ } \\
\text { sponsorships) }\end{array}$ & $\begin{array}{c}\text { Government } \\
\text { Support }\end{array}$ & $\begin{array}{c}\text { Other } \\
\text { Revenue } \\
\text { Sources }\end{array}$ & Total \\
\hline NCSM & 116.32 & 15.00 & 290.88 & 26.80 & 449.00 \\
\hline $\begin{array}{c}\text { Tamilnadu Science \& } \\
\text { Technology Centre }\end{array}$ & 4.3 & - & 14.54 & 0.35 & 19.19 \\
\hline $\begin{array}{c}\text { Kerala State Science \& } \\
\text { Technology Centre, the }\end{array}$ & 2.36 & - & 9.00 & .084 & 11.44 \\
\hline The Birla Musum, Pilani & .95 & - & - & 5.00 & 5.95 \\
\hline $\begin{array}{c}\text { Sukanta Academy, } \\
\text { Agartala }\end{array}$ & .05 & - & 3.00 & & 3.05 \\
\hline $\begin{array}{c}\text { B.M. Birla Science Centre, } \\
\text { Hyderabad }\end{array}$ & 10.00 & - & - & 2.50 & 12.50 \\
\hline
\end{tabular}


The Science Museums and Science Centres earn revenue through sale of entry tickets, admission to special exhibitions, sponsorships and sale of exhibits and equipment as catalytic support to other institutions.

\section{CHAPTER 8 THE CHALLENGES}

The major objectives of the science museums and science centres operating in India are, inter alia

- Popularisation of Science

- Creation of a scientific temper - fighting superstition \& obscurantism

- To supplement Science \& Technology education given in formal educational institutions

- To organise outreach programmes on Science \& Technology to reach the people at large

- To collect and disseminate information in regard to Science \& Technology

- To actively engage in building up scientific manpower

- To generate a scientific culture in the present knowledge-based society.

However, with the changing world order, these objectives are to be fulfilled to cope up with the social changes, technology changes and also with factors like globalisation. In the current scenario when India is emerging as an industrial power globally, it has become necessary for the average Indian citizen to take part in the decision making process for introduction of new technologies and their products. This is possible only when people are aware of the important issues related to Science \& Technology. Therefore, more and more people are to be accessed by the Science Museums and Science Centres for spreading the message of Science \& Technology in a bigger way. With about 40 science centres working in the country, the number of people visiting science centres currently is just $1 \%$ of the total population. With the introduction of science communication through the virtual medium, it will reach perhaps $2 \%$ soon. A very major challenge, therefore, is to regenerate the non-formal science education activities at the school, community group and other grass-root levels.

The following indicate other major challenges faced by Indian science centres.

\section{Infrastructure Growth \& Funds}

Growth of Science Centres has been too fast in the past. Quality and consolidation of the network are the key challenges now. The growth of Science Centres in India under the single umbrella of NCSM need to be limited before it grows too big to be administered properly. Further growth has to occur at the users' location, using local fund and support. This may not necessarily be government fund. Availability of private endowment fund or business house sponsorship for non-profit institutions is not as prolific in India as in many other countries. But as government funding is limited, generation of sponsorship for science centre funding is a key issue in India. At present, encouraging responses from large corporate houses and Public Sector Units (PSU) have started coming. During 
the last two years, total amount of contribution to NCSM from Corporate Bodies and PSUs crossed 50 million Rupees.

\section{The Decline of Career In Science}

In the '50s, students in the middle-top level took to science streams while the quality has shifted now and high-school students opting for science are from lower levels of the catchment population. An overwhelming majority of students with high quality performance opt out of science streams. This is, however, not the case with engineering and medical streams which still attracts the top school graduates. In the Indian scenario, there has been a phenomenal growth in the number of institutions imparting science education and in the number of students enrolling in science stream. At the undergraduate level, such enrolment was 125,000 in 1950 and by 2000 it has increased more than ten fold.

Despite this outstanding growth in numbers, the overall percentage of school students opting for science has consistently declined over the years.

$$
\begin{aligned}
& 1950-32 \% \\
& 1986-20 \% \\
& 2000-15 \%
\end{aligned}
$$

If we try to find out the reasons for this decline and look into our formal science education system at the school level and at the under-graduate level, it may be seen that a large number, around $90 \%$ of undergraduate science students, is educated in university affiliated colleges. Many of these colleges are overcrowded, under equipped in laboratory and library facilities, and poorly staffed. Undergraduate science education programme has now become entirely chalk-talk-rote routine without any emphasis on understanding of the basic concepts and the unity of the subject. Class room demonstrations and openended experimentation have all but disappeared from the undergraduate programmes (although science is truly experiment based). This depressing environment curbs the inherent and natural excitement of doing science. The examination system has contributed furthe $r$ to the deterioration of science education as it emphasizes on memory and rote rather than on analytical ability and fresh thinking. Even then the dropout and failure rate is quite high at around $40 \%$. There are nonetheless an exceptional few institutions that still heroically seek to offer science education comparable to the best, however they are confronted with outmoded curricula and rigidity of institutional set-up of the universities and are thus unable to make significant impact on the general scene.

As a consequence, thrill and fun in learning science has decreased.

Science Centre activities can very effectively and substantially fill up what is lacking and bring back quality in science learning through an interactive doing-science approach.

\section{Getting the right people}

In India the profession in Science Communication is growing but there is no formal supportfrom the academic world. No accredited course on Science Communication suitable to Science Centre needs is conducted in Indian Universities. Training, motivation 
and empowerment of staff to the optimum level are difficult challenges considering that Science Centre activities, after all, need a more than normal level of energy and dedication.

The job opportunity pattern for university graduates has undergone sea-change in the last few years. In India, the share of the government or government supported organisations in the job market has reduced considerably. There has been notable shift between different sectors of economy and this shift has gone in favour of the service sector basically the IT, communication, banking and financial services.

In the global market, Indian skill and trained human resources in the service sector has been recognised. This draws talented students to such sectors and they do not see a career in science to be rewarding and satisfying.

The science research scenario, except in some sectors, is stagnating.

\section{Building on strengths}

Exhibit development capability of NCSM is well known. Some of the activities directed to rural communities in India like the Mobile Science Exhibitions (MSE) are popular. To which extent these are to be marketed? Strong marketing drives sometimes diverts working groups from core activity area.

Another important initiative taken by the Council relates to marketing of its facilities and expertise in exhibit development. The demand shows that the market is growing in India and also overseas. An expert committee has been formed by the Governing Body of NCSM to look into this matter for a suitable recommendation for the course of action to be taken in the coming years. The marketing efforts have resulted in a three-fold increase in revenue earning during the last six years.

\section{CHAPTER 9}

\section{THE ROLE OF SCIENCE CENTRES TO MEET THE CHALLENGE}

"Spread scientific temper into our lives to spur innovation, defined as newness in thinkingand action. In other words, do whatever we are doing, individually or collectively, in more efficient, more satisfying ways".

Mr. Atal Behari Vajpayee Prime Minister of India

The Science Centre activities can present the thrill of science to the students starting from the school level and therefore, supplement formal school education by its doingscience approach. This thrill may eventually shift a part of this student population to a career in science. No country can progress without emphasis on research and development in different scientific fields. It is important to develop a strategy so that trained manpower can be developed in the long run. In the short run, it is felt, in many countries, that talent is not going to the field of science. If immediate action is not taken, there will be a decline in scientific, economic and social progress in future.

The Hon'ble Prime Minister of Mauritius in one of his speeches expressed that

"Science occupies an important place in this technology and knowledge-based era. The world today is undergoing unprecedented and far-reaching changes following 
considerable developments in the field of Information and Communications Technology. Access to knowledge has become a key factor in the New Economy. The achievements of a country and its people are now being determined by their capacity to master new technologies. We need to learn new skills and adapt ourselves to technological innovation. In pursuance of this objective, Government is providing unprecedented facilities in terms of infrastructure, education and training. We all agree that Governments and educational institutions have to address a dramatic mismatch between the future needs of the country and the interest in science shown by our students. In fact, a recent study undertaken by the Tertiary Education Commission has revealed that the percentage of students opting for science subjects at tertiary level is low in relation to our future economic expectations".

- Extract from the speech of the Hon'ble Prime Minister of Mauritius Sir Anerood Jugnauth

\section{Science \& Technology Policies of the Government of India}

The policies of the Government of India related to Science \& Technology Museums and Centres received a thrust when a Task Force constituted by the Planning Commission of the Government of India recommended fast growth in infrastructure and activities of science museums. Riding on these recommendations, the present infrastructure of about 40 science museums and science centres has been created. Considering the very important role, these institutions are playing in disseminating the message of science to the citizens of India, the Government of India has strongly recommended promotion of science museums and similar institutions for spreading the message of science in the country. The S\&T Policy of the Government of India published in 2003 has, inter alia, have provisions

- to ensure that the message of science reaches every citizen of India, man and woman, young and old, so that we advance scientific temper, emerge as a progressive and enlightened society, and make it possible for all our people to participate fully in the development of science and technology and its application for human welfare. Indeed, science and technology will be fully integrated with all spheres of national activity;

- to vigorously foster scientific research in universities and other academic, scientific and engineering institutions; and attract the brightest young persons to careers in science and technology, by conveying a sense of excitement concerning the advancing frontiers, and by creating suitable employment opportunities for them. Also to build and maintain centres of excellence, which will raise the level of work in selected areas to the highest international standards;

- to promote the empowerment of women in all science and technology activities and ensure their full and equal participation;

- to provide necessary autonomy and freedom of functioning for all academic and R\&D institutions so that an ambience for truly creative work is encouraged, while ensuring at the same time that the science and technology enterprise in the country is fully committed to its social responsibilities and commitments;

- to use the full potential of modern science and technology to protect, preserve, evaluate, update, add value to, and utilize the extensive knowledge acquired over the long civilizational experience of India; 
- to ensure, in an era in which information is key to the development of science and technology, that all efforts are made to have high-speed access to information, both in quality and quantity, at affordable costs; and also create digitized, valid and usable content of Indian origin;

- to promote international science and technology cooperation towards achieving the goals of national development and security, and make it a key element of our international relations.

Public awareness of Science \& Technology constitutes an important part of the latest S\&T Policy (2003) of the Government of India. While formulating the relevant strategy for achieving public awareness, the Policy notes that

- there is growing need to enhance public awareness of the importance of science and technology in everyday life, and the directions where science and technology is taking us. People must be able to consider the implications of emerging science and technology options in areas which impinge directly upon their lives, including the ethical and moral, legal, social and economic aspects. In recent years, advances in biotechnology and information technology have dramatically increased public interest in technology options in wide ranging areas. Scientific work and policies arising from these have to be highly transparent and widely understood;

- support for wide dissemination of scientific knowledge, through the support of science museums, planetaria, botanical gardens and the like, will be enhanced;

- every effort will be made to convey to the young the excitement in scientific and technological advances and to instill scientific temper in the population at large;

- special support will be provided for programmes that seek to popularize and promote science and technology in all parts of the country. Programmes will also be deve loped to promote learning and dissemination of science through the various national languages, to enable effective science communication at all levels. In general the activities of science museums and science centres have been identified as an area for promoting public awareness of science \& technology and the Government of India has given a special thrust in this area.

\section{Thoughts for the Future}

When the NCSM was formed in 1978, the topmost priority was expansion of the Science Museum and Science Centre network in India. With a fairly large network already established now, the priority has shifted to quality, consolidation and more efficient communication. The new research and training facilities will be strengthened further to generate new exhibits, new display techniques and trained manpower. All the units of the Council located in different parts of the country will be connected through ISDN lines and also through satellites to enlarge the base for real-time programme sharing. The Council is poised to take up more science communication activities on the digital medium and this endeavour will be reinforced in the coming years.

Growth of infrastructure will continue in future as the demand is high in India. However, for setting up new Science Centres, the Council will be more in the role of a consultant. The activities will be regenerative at the local level. 
The Indian Science Centres at present are carefully studying and assessing the impact of their activities at the individual, societal and economic levels. Assessment studies have been initiated and the feedback will be used to modify the programmes if necessary, for better efficiency and higher impact. With the adoption of new technologies and new approaches in exhibit presentations, Indian Science Centres are trying to remain relevant to the society.

This, of course, is a very important aspect of the Science Centre movement in a country like India where diversities in language, customs, local issues and scientific illiteracy are major social issues. Eleven new Science Centres and two large Science Cities are at present in the making in different parts of the country. 